\title{
Cultural Properties as a Source for Learning History: A Case Study in Cilacap Regency, Indonesia
}

\author{
Suswandari \\ Universitas Muhammadiyah Prof. DR. HAMKA \\ suswandari@uhamka.ac.id
}

\begin{abstract}
This research aims to identify the potential of cultural property in Cilacap Regency as a source for learning history. The research is conducted using qualitative approach through three stages, namely identifying cultural property that can be used as a source for learning history and educational tourism, assessing the response of history teachers on the use of cultural property as a source for learning history, and assessing the strategy of using cultural property as learning sources. The results show that (1) Cilacap has 84 potential cultural properties that can be developed as learning resources. (2) The potential of the cultural properties has not been fully utilized by teachers as a source for learning history. (3) The reasons behind this are the teacher's lack of information about the cultural properties and the distance between the location of the cultural properties and the school. (4) History teachers in Cilacap use project-based learning as a method of using cultural properties as a learning resource.
\end{abstract}

Keywords: cultural property, source for learning history, Cilacap regency

\section{INTRODUCTION}

Cultural property reflects a nation's civilization. It is a medium that conveys both material and nonmaterial values. The government has issued Law No. 11 of 2010 on cultural conservation. It means that the conversation of cultural property is not only to conserve cultural products, but also to have a role in economy, social and political sectors. Even the good utilization of cultural property can be a new economic source for the surrounding community. The development of the sites and artifacts of the Sultanate Ternate and Sultanate by the local government of North Maluku is one of the examples [1]. A study conducted by Stetic [2] found that cultural property is one of the potential tourism attributes, if it is formed and managed with great attention. It is also supported by Sunardi [3] who states that cultural property is an important factor that support regional and national development when it is used as an attractive tourist destination since cultural properties are unique, rare, non-renewable and non-replaceable by technology or the same materials. Most important,

\author{
Laely Armiyati \\ Universitas Muhammadiyah Prof. DR. HAMKA \\ laelyarmiyati@uhamka.ac.id
}

the properties are proofs of human activities in the past.

Cilacap Regency is one of the southernmost regencies in Central Java province that has the potential of interesting and unique cultural properties. Also, it has a potential of an educative tourism associated with past historical facts. However, only limited number of these properties are used by teachers, especially history teachers. It is an unfortunate situation because the cultural property actually has many advantages, not only to increase student's interest but also to improve their grades on the subject ([4].

This research attempts to identify cultural properties that can be utilized for learning resources and analyze some strategies of using cultural properties for learning.

\section{METHOD}

This research used qualitative approach because it research analyzes and describes phenomena, events, social activities, attitudes, beliefs, perceptions, and thoughts of individuals and groups [5]. This research was conducted through three stages. The first stage is identifying the cultural properties that can be used as a source for learning history and educational tourism. The second stage is analyzing history teachers' responses on the use of cultural properties as a source for learning history, and the third is analyzing the use of cultural property as a strategy of learning history and a potential educational tourism.

\section{RESULT}

\section{Geographical Description of Cilacap Regency}

Cilacap regency is located in Central Java Province. Cilacap is the largest Regency in Central Java, covering $6.9 \%$ of the total area. It is bounded by Indian Ocean on the south, on the north by Banyumas Regency, Brebes Regency and Kuningan Regency of West Java province, on the east by Kebumen Regency, and on the west by Ciamis Regency and Banjar City of West Java [6]. 
Table 1. List of Cultural Property Sites in Cilacap Regency

\begin{tabular}{|l|l|}
\hline \multicolumn{1}{|c|}{ Names of Cultural Properties } & \multicolumn{1}{|c|}{ Location } \\
\hline Pendem Fortress & $\begin{array}{l}\text { Benteng, Cilacap, South Cilaca., Cilacap Regency, } \\
\text { Central Java, 53211 }\end{array}$ \\
\hline Watu Lingga & $\begin{array}{l}\text { Pesanggrahan Village, Sub-district of Kesugihan, } \\
\text { Cilacap }\end{array}$ \\
\hline Situs Candi Jambu & Cilongkrang Village, Sub-district of Wanareja \\
\hline Klingker Fortress or Banju Njappa & Nusakambangan \\
\hline Maos Station & Sub-district of Maos \\
\hline Karang Bolong Fortress & Nusakambangan \\
\hline $\begin{array}{l}\text { Residence of District Military Command Chief of } \\
\text { Staff }\end{array}$ & Jl. Jend. Sudirman, Tegalsari, Cilacap \\
\hline Department of Tourism Office, Cilacap & Jl. Jend. A. Yani, Sidakaya, Cilacap \\
\hline
\end{tabular}

Source: Department of Culture and Tourism of Cilacap Regency [7]

The Potential Cultural Properties as a Source for Learning History and Educational Tourism in Cilacap Regency

Based on the data from the Department of Culture and Tourism of Cilacap Regency, there are 84 cultural property listed in Cilacap Regency. Six of those have been included in the national registration of cultural properties and 78 others are immovable cultural objects. Some of the properties as listed in Table 1.

In 2016, there were six cultural properties in Cilacap Regency that had been officially registered for protection and maintenance by the central government, including the Department of Tourism of Cilacap Regency, the Hong Bangkong Suralaka Cemetery, the Ancient Bell, the Regent Office Gate, and the Sleeping Place of Cilacap Regent.

\section{Cultural Properties as a Source for Learning History and Educational Tourism}

The findings of this research suggest that the existence of cultural property in Cilacap has great potential to serve as a source for learning history. The following table presents the classification of some cultural properties that can be used as a source for learning history in high school, which is in accordance with the school-based curriculum (KTSP) as a recommended curriculum at the time this research was taking place.

The data shows that most of the historical heritage in the area of Cilacap Regency were relics from the Dutch East Indies. It proves the importance of Cilacap city during the period of Dutch East Indies, especially as the gate of transferring goods that were going to be exported to the Netherlands. However, the locations of the cultural properties were not divided evenly, but centered in one area. This condition frequently became the reason why the teachers did not utilize the cultural properties as a learning resource. In order to overcome this problem, the assistance from the government and private institutions is needed to provide transportation facilities, especially in providing better and easier access to the cultural properties.

Based on the results of the surveys and interviews with history teachers, there were many teachers who had not utilized the cultural properties for teaching history. Nevertheless, there were several attempts made by the teachers to optimize the existence of the cultural properties in their environment as a source for learning. Some of the reasons for not utilizing the cultural properties in history learning revealed by some partcipants are as follow:

"...there are too many materials, so there is no time to visit the cultural heritage. The location is too far away so it is rather costly. Also, there are some teachers who do not know that a potential cultural heritage exists".

AMA, another history teacher in a high school in Cilacap also stated,

"... the location of cultural properties is too far from the school, and the area of Cilacap Regency is very wide and the distance between the Sub-district is also too far. This is a barrier to utilize the cultural property as a learning resource.".

The utilization of cultural property as a source for learning history is very essential since historical science is best learned through visualization that helps the students understand and experience important historical events. The existence of cultural properties as an evidence of the past historical events will greatly support the learning process. The following statement by UW, a history teacher, reflects this opinion. 
Table 2. The Classification of Cultural Properties in Cilacap Regency as a Source of Learning History

\begin{tabular}{|c|c|c|c|}
\hline${ }_{\text {ss }}$ Cla & Topics & Cultural Properties & Locations \\
\hline \multirow[t]{4}{*}{$\mathrm{X}$} & \multirow{4}{*}{$\begin{array}{l}\text { The Period of } \\
\text { Hinduism and } \\
\text { Buddhism }\end{array}$} & Pabahan Site & Majenang \\
\hline & & Jambu Temple Site & Cilongkrang, Majenang \\
\hline & & Watu Lingga & Pesanggrahan \\
\hline & & The Cilacap Regent Office Gate & Cilacap \\
\hline \multirow[t]{8}{*}{$\mathrm{XI}$} & \multirow{8}{*}{$\begin{array}{l}\text { Colonialism and } \\
\text { Imperialism Era }\end{array}$} & Pendem Fortress & Penyu Bay, Cilacap \\
\hline & & Karang Bolong Fortress & Nusakambangan \\
\hline & & Klingker Fortress & Nusakambangan \\
\hline & & Railway Station & $\begin{array}{l}\text { Cilacap, Maos, Kesugihan, } \\
\text { Karangkandri, Gumilir, Jeruklegi, } \\
\text { Kawunganten, Gandrungmangu, } \\
\text { Sidareja, Cipari. }\end{array}$ \\
\hline & & $\begin{array}{l}\text { The Department of Youth, Sport } \\
\text { and Tourism Office of Cilacap } \\
\text { Regency }\end{array}$ & Sidakaya, Cilacap \\
\hline & & Kerkhoff Cemetery & Cilacap \\
\hline & & Afdeling Office & Majenang \\
\hline & & $\begin{array}{lll}\begin{array}{l}\text { Railway } \\
\text { Residence }\end{array} & \text { Station } & \text { Official } \\
& & \end{array}$ & $\begin{array}{lr}\text { Kroya, Maos, } & \text { Kesugihan, } \\
\text { Karangkandri, Gumilir, Cilacap, } & \text { Kawunganten, } \\
\text { Jeruklegi, } & \text { Kandrungmangu, } \\
\text { Gandrungun, } \\
\text { Bedengan, Cipari }\end{array}$ \\
\hline XI & $\begin{array}{c}\text { Japanese } \\
\text { Colonialism Era }\end{array}$ & Japanese Fortress & Mt.Selok, Cilacap \\
\hline XI & $\begin{array}{l}\text { Independence } \\
\text { Revolution Era }\end{array}$ & Kiai Sumolangu Tomb & Mt. Selok, Cilacap \\
\hline
\end{tabular}

"I think it important to use the cultural properties in learning history, because the cultural properties are a historical evidence. If the students learn history with the evidence, it will be easier for them, so they are not just wandering. In utilizing cultural properties, I am applying the project method. Usually, I assign students to work in groups to conduct surveys by visiting tourist attraction, gathering information about the object, and then reporting information they have collected.......... With students collecting the information themselves, they will have their own interests, and I think it will be more effective".

The statement is supported by other participant, $\mathrm{SH}$, who stated that the use of cultural property helps to make the learning of history easier, more interactive and more fun.

"The utilization of cultural property can be done by linking a class topic to a cultural property. For example, colonialism topic can be connected to Fortress Pendem. By doing so, teachers can facilitate the students in understanding important historical events. Moreover, it is not only beneficial for students but also for the existance of Fortress Pendem".

Therefore, history teachers in Cilacap prefer the project method in the utilization of cultural properties as it is considered suitable for the student-centered learning approach. This approach suggests that students are the focus of instruction. Using this method, teachers apply a scientific approach that encourages students to build their own knowledge (constructivism), so the students will remember the materials more easily.

However, cultural properties in Cilacap have not been optimally utilized, especially by history teachers. The main constraints are the lack of information and the distance of the cultural properties from the school. Therefore, an effort needs to be made to solve the constraints. One of them is by involving the local government through the development of the potential of educational tourism.

\section{The Strategy of Utilizing Cultural Property as a Source for Learning History}

Cultural property can be used as a source for learning history through various methods. Based on observations and interviews with history teachers in Cilacap, the appropriate method of utilizing cultural property is through project-based learning. The project-based learning is one of the recommended methods in the Curriculum of 2013. It is a method that uses a project or activity as the core of learning. In this activity, students conduct exploration, assessment, interpretation, synthesis, and find information to produce various forms of learning outcomes. The project-based learning is best done in groups to improve students' ability to work with other 
people who have different characteristics and abilities from their own.

The following are some steps to utilize cultural properties as a source for learning history:

a. Conduct needs analysis, including material needs, students, and skills or abilities to be achieved.

b. Determine the location of cultural property that is relevant to the needs.

c. Decide the the learning method such as project learning or problem-based learning. It is recommended to choose a learning method that mainly focuses on students (i.e student-centered learning).

d. Create materials/tasks/ projects that will learned/done by students.

e. Divide the students into groups.

f. Assign each group to do specific materials/tasks/projects.

g. Conduct studies at cultural property sites.

h. Ask the students to present the tasks/ results of their studies.

There are various learning methods that can be used when utilizing cultural property as a learning resource. However, choosing a student-centered learning method is highly recommended since it is based on the foundation of constructivism philosophy. By using this approach, students will build their knowledge and understanding. It will also help the students hone their cognitive, affective and psychomotoric functions so the learning objectives will be achieved.

\section{CONCLUSION}

Cilacap Regency has 84 cultural properties that have been inventoried by the Department of Youth, Sports, and Tourism, but only six of them have been registered nationally. Meanwhile, these cultural properties were not optimally utilized for history learning resources due to limited information about the cultural properties for many history teachers in Cilacap. However, some of the cultural properties have been used by history teachers through projectbased learning. By using this method, the learning becomes more effective as it increases student's motivation in learning history.

\section{REFERENCES}

[1] Suswandari, S. Ternate Historical Site as an Object Based Education for Sustainable Development. JETL (Journal Of Education, Teaching and Learning), 2(2), 151-163. 2017.

[2] Stetic, S. Specific features of rural tourism destinations management. Journal of Settlements and Spatial Planning, 131. 2012

[3] Sunardi. Kandidat Doktor Unissula Desak Perlindungan Cagar Budaya. 2016

[4] Ventyasari, R. Pemanfaatan Museum Trinil Sebagai Sumber Belajar Sejarah Bagi Siswa SMA Di Kabupaten Madiun Provinsi Jawa Timur Tahun Ajaran 2014/2015. Universitas Negeri Semarang. 2015

[5] Mulyana, D. Metodologi penelitian kualitatif: paradigma baru ilmu komunikasi dan ilmu sosial lainnya. Bandung: PT Remaja Rosdakarya, 2006

[6] BPS Kabupaten Cilacap. Data Kependudukan. Cilacap: BPS, 2006

[7] Dinas Pariwisata Kabupaten Cilacap. Laporan Inventarisasi Cagar Budaya Tidak Bergerak Kabupaten Cilacap, Balai Pelestarian Cagar Budaya Jawa Tengah 2013. Kabupaten Cilacap, 2013 